Aufbau der zusammenhangenden Materie

Redigiert von A. Smekal. Pp. xiv +1203. ("Handbuch der Physik". Herausgegeben von H. Geiger und Karl Scheel. Zweite Auflage. Bd. 24, Teil 2.) (Berlin : Julius Springer, 1933.) 129 gold marks.

ONE hundred and twenty-nine gold marks may seem a very stiff price to pay for a scientific book even when advantage may be taken of the new facilities for purchasing German books at 25 per cent discount, but the present volume is exceptional in many ways. It contains some 1200 pages of excellently printed matter, and the subjects treated are such that it could not well have been inexpensively produced. It is well supplied with tables and diagrams, and little or no attempt has been made to save expense by undue curtailment of the mathematical treatment. One may legitimately look at the six chapters and ask oneself, in considering the cost, how much one would expect to pay for the excellent 300 page treatise on the electron theory of metals by Sommerfeld and Bethe, if it were issued in separate covers ; or, again, what would be the market price of a book of 200 pages on atomic structure and chemistry, by Grimm and Wolff.

The plan followed is very satisfactory. Herzfeld writes on the size and structure of molecules, considers their electric properties, their band spectra and the forces between them in the various states of aggregation. Perhaps one may say that English readers will be surprised that he does not devote more space to viscosity formulæ in his comprehensive survey. Kronig deals with the relations between molecular attractions and the structure of crystals, and includes a neat account of the significance of the fine structure observed in the edges of X-ray absorption bands. Then follows the compact treatment of the electron theory of metals given by Sommerfeld and Bethe; it is doubtful whether some of the properties of metals here discussed have previously been described in so clear and concise a manner. The problems of the crystal lattice are examined by Born and Goppert-Mayer, Smekal deals with the factors which influence the properties of crystals, and the article by Grimm and Wolff completes the book.

It is an important contribution to the literature of modern physics and chemistry, and a work which will frequently be consulted by most research workers interested in modern theory. From this point of view it is a pity that the book is not issued in two or more separate parts.

L. F. B.

Leçons $\mathrm{d}$ algebre et de geometrie a 1 usage des etudiants des Facultes des Sciences

Par Prof. Rene Garmier. D'Apres la redaction de Badrig Guendjian. Tome 1: Algèbre lineaire, homographie, equations tangentielles. Pp. viii +233 . (Cours de la Faculte des Sciences de Paris.) (Paris : Gauthier-Villars, 1935.) 40 francs.

THIs book has been specially written by Prof. Garnier for mathematical students taking a course in the faculty of science at Paris. It is essentially a theoretical treatise embracing four chapters on linear algebra; two on the classic theorems of both plane and solid projective geometry and one on tangential equations. The treatment is wholly analytical and, as the author points out in the preface, the most general methods have been applied in establishing the fundamental propositions. Centres and diameters of conics, for example, are derived as special cases of poles and polars.

The text has been very clearly written, and it is difficult to discriminate between the excellence of the various chapters. Special mention, however, should be made of the brilliant analytical discussions on enharmonic ratios and envelopes. These, in spite of their generality, should not fail to stimulate a keen interest in the reader. If the book has a defect at all, it is that common to most French textbooks, for there are no exercises provided for the student's practice.

\section{Toxikologische Mikroanalyse:}

Qualitative Mikrochemie der Gifte u.a. gerichtlichchemisch wichtiger Stoffe. Von Prof. Dr. L. Rosenthaler. Pp. viii +368. (Berlin: Gebrüder Borntraeger, 1935.) 25.50 gold marks.

THIs work may be regarded to a large extent as complementary to Dr. Rosenthaler's "Der Nachweis organischer Verbindungen" (Stuttgart, 1923), in which he treats of macro-analytical methods in organic chemistry. In the new volume he gives a comprehensive and reliable account of the many micro-methods which are now available for the detection of poisons, whether in traces or otherwise. As he points out, forensic chemistry offers a particularly favourable field for the application of microanalytical methods.

The book gives a short general account (19 pp.) of micro-methods for sublimation, distillation, electroanalysis, spectro-analysis, erystallisation, etc., followed by descriptions of diagnostic tests for specific inorganic (76 pp.) and organic (259 pp.) substances.

The book is well printed, and there are numerous illustrations, chiefly of crystalline derivatives prepared in the various tests; it should prove of use to practical workers in forensic medicine and analytical chemistry in general.

J. R.

\section{Value and Existence}

By Prof. N. O. Lossky and Prof. John S. Marshall, Pp. 223. (London: George Allen and Unwin, Ltd., 1935.) 7s. 6d. net.

AT a time when materialism appears to be at a discount, it is natural that discussions on the problem of values become more and more pressing. To such discussions, Prof. Lossky contributes an excellent monograph in which the notions of value and existence are interpreted in terms of a Neo-Platonism tempered by Christian ideals. Where true absolute concrete consubstantiality lies and how it is related to this world, are the two aspects of the problem dealt with in part 1 of the book. In the second part, which is contributed by Prof. Marshall, we find an explanation of some basic conceptions of Prof. Lossky's viows.
T. G. 